\title{
Both a biopsy method and a therapeutic procedure in BI-RADS 4A and 4B lesions: Ultrasound-guided vacuum- assisted breast biopsy
}

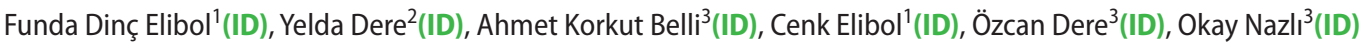

${ }^{1}$ Department of Radiology, Mugla Sitki Kocman University School of Medicine, Mugla, Turkey

${ }^{2}$ Department of Pathology, Mugla Sitki Kocman University School of Medicine, Pathology, Mugla, Turkey

${ }^{3}$ Department of General Surgery, Mugla Sitki Kocman University School of Medicine, Mugla, Turkey

\section{ABSTRACT}

Objective: This study aimed to evaluate outcomes, complications, and follow-up results of ultrasound-guided vacuum-assisted breast biopsy (UG$\mathrm{VABB}$ ) in BI-RADS $4 \mathrm{~A}$ and $\mathrm{B}$ lesions.

Material and Methods: Between Agust 2014 to January 2018, fifty BI-RADS 4A and BI-RADS 4B lesions of 41 patients biopsied with 10G vacuum needle by a single radiologist were retrospectively evaluated.

Results: All patients were females and mean age of the 41 patients was $50.12 \pm 8.63$. Of all lesions, $84 \%$ was benign, $6 \%$ was $A D H, 4 \%$ was in-situ cancer, and $6 \%$ was diagnosed as malign. Follow-up duration after VABB was 0-51 months and mean was 20.92 months. Complications were as vasovagalinduced seizure in 3 patients (7.3\%) and intramammary hematoma in 16 patients (39\%). Hematoma was diagnosed in 3 patients (7.3\%) at the $6^{\text {th }}$ month follow-up and it was resolved in all patients at the $12^{\text {th }}$ month follow-up. Higher breast density resulted in higher hematoma rates. There was no relationship between lesion BI-RADS subgroups, lesion size or sample number and hematoma development. During the follow-up, residue lesion in 1 (2.4\%) patient and scar tissue in 2 (4.9\%) patients was detected.

Conclusion: US-guided VABB, with low complication rates and low scar development, is also a therapeutic excision method without remaining residue, which should be primarily preferred in smaller than $2 \mathrm{~cm}$ BI-RADS 4A and 4B lesions whose malignancy rates are relatively low. Hematoma, which is the most frequent complication, resorbed entirely in the $12^{\text {th }}$ month in all patients.

Keywords: Ultrasound-guided, vacuum-aspiration biopsy, BI-RADS, complication, treatment

Cite this article as: Dinç Elibol F, Dere Y, Belli AK, Elibol C, Dere Ö, Nazlı O. Both a biopsy method and a therapeutic procedure in BI-RADS $4 \mathrm{~A}$ and $4 \mathrm{~B}$ lesions: Ultrasound-guided vacuum-assisted breast biopsy. Turk J Surg 2020; 36 (1): 65 71.

Corresponding Author

Funda Dinç Elibol

E-mail: fundadi@yahoo.com

Received: 02.03 .2019

Accepted: 25.11 .2019

Available Online Date: 18.03 .2020

( Copyright 2020 by Turkish Surgical Society Available online at www.turkjsurg.com

DOI: $10.5578 /$ turkjsurg.4472

\section{INTRODUCTION}

Percutaneous imaging-guided breast biopsies are easy, reliable and cost-effective that has taken the place of excisional biopsies and thus, the form of standard diagnostic procedure (1-4). Percutaneous biopsies could be performed through stereotactic or ultrasound guidance. It is a biopsy method primarily preferred and used very commonly with mammography in stereotactic vacuum-assisted breast biopsy (VABB) for microcalcifications (2). In the literature regarding VABB, greatest majority of the studies are about mammography guided stereotactic microcalcification biopsies or MRI guided biopsies of MRI-only lesions $(5,6)$. Ultrasound (US)-guided VABB, which can even be used in biopsies of calcifications, is a real-time biopsy method preferred in breast biopsies that does not involve ionizing radiation $(2,7)$. Besides, it has been indicated that it is a method which can be preferred confidently in complete excision of benign lesions and can be tolerated by patients easily (8-10). In this manner, our aim in this study was to assess outcomes, complications, and follow-up results of US-guided VABB performed in lesions classified as category $4 \mathrm{~A}$ and $\mathrm{AB}$ in which malignancy rates are relatively low according to breast imaging-reporting and data system (BI-RADS).

\section{MATERIAL and METHODS}

We analyzed 58 breast lesions of 48 consecutive patients who underwent US-guided VABB in our hospital from August 2014 to January 2018. In BI-RADS 3 lesions, US-guided VABB was performed for total excision of the lesion due to the request 
of the patients and clinicians. In BI-RADS 4C and 5 lesions which were biopsied with vacuum-aspiration, this biopsy method was preferred to decrease false negativity of the biopsy depending on the lesions small size. Patients classified as BI-RADS 4A and BI-RADS 4B were biopsied with the vacuum-aspiration method if the longest diameter of the lesion was $\leq 20 \mathrm{~mm}$. US-guided VABB was performed in consecutive patients who accepted this procedure and provided appropriate conditions.

BI-RADS 3 lesions were excluded from the study as their benignancy was over $98 \%$ and BI-RADS category 4 C lesions were also excluded due to their high malignancy rates. Totally, 7 cases and their 8 lesions (BI-RADS 3: 5 lesions in 4 patients, BI-RADS 4C: 2 lesion in 2 patients, BI-RADS 5: 1 lesion in 1 patient) were excluded from the study. Fifty BI-RADS 4A and BI-RADS $4 B$ lesions, belonging totally to 41 patients, were included into the study. Stereotactic vacuum aspiration biopsies administrated for microcalcifications were not included in the study. All patients were assessed by only one radiologist prior to biopsy, and ultrasonography of all patients were executed by the same radiologist. In the patients treated with warfarin or aspirin, a method other than US-guided VABB was preferred for biopsy.

All biopsies were performed with a $10 \mathrm{G}$ needle using the BARD Encore Enspire (BDI, Becton Dickinson, New Jersey America) multidirectional VABB device. The device has a suction chamber attached to the needle. The needle has a rotary blade and blade can rotate $60,120,180$, and 360 degrees. The vacuum draws the tissue into the aperture of the needle and the rotary blade slices the lesion. Each specimen is transported to a port chamber by the effect of vacuum. VABB was performed with the guidance of real-time ultrasound, Toshiba Aplio 500 (Toshiba Medical System Corporation, Tokyo, Japan) with a 7-12 MHz probe.

Following the cleaning and covering of the biopsy site, covering the ultrasound probe with a sterile tunic, and after practicing standard $10 \mathrm{~mL}$ local anesthetic ( $2 \%$ prilocaine) to the site of the tractus, an approximately $5 \mathrm{~mm}$ incision was made in sterile conditions. Vacuum aspiration needle was placed in the guidance of the US to the center or posterior of the lesion according to the position of the lesion, and rotary cutting of the lesions was performed under US monitoring. Aspiration biopsy in various angles (60 to 360 degrees) continued till the lesion could not be entirely monitored. 5-29 times aspiration was executed for the patients according to the dimension of the lesions. A $10 \mathrm{cc}$ more local anesthetic was injected through the VABB device without pulling the needle to the patients who felt pain during the biopsy. The aspiration feature of the device was benefitted from in providing hemostasis and manual compression after pulling the needle. Completed excision of the mass was described as documentation of the absence of any residual lesion seen by obtaining longitudinal and transverse sonograms to the area of excision. Successful excision was also established by first-year control mammography of the lesions in which index lesion was able to be seen in initial mammograms. Follow up data of the patients were performed by the same radiologist in the first month, $6^{\text {th }}$ month with ultrasonography and $1^{\text {st }}$ year with ultrasonography and mammography. Complications, which developed during the operation, were recorded and biopsy site was evaluated in terms of the residual lesion, hematoma and scar tissue in the follow-up. After the biopsy, the samples were examined by routine histopathological procedures. All biopsies were reviewed and diagnosed by the same pathologist.

This study had been approved by our medical school's Institutional Reviews Board (number 04/III date 05.04.2018). Informed consent was taken from all patients prior to biopsy.

\section{Statistical Analysis}

The shapes of distribution of the measured variables were demonstrated using the Shapiro-Wilk method. The test results indicated a normal distribution of data, allowing parametric tests to proceed for further analysis. Mean and standard deviation values of the parameters were executed to describe scale variables. Independent samples t-test was administrated for normally distributed parameters. Inter-group difference for categorical variables was evaluated by the Chi-square test and presented with the percentage along with the number of observations. In order to understand the cause and effect relationship between continuous variable (as an independent factor) and the categorical variable (as a dependent factor), binary logistic regression analysis was employed since the outcome variable consisted two subcategories. Statistical analyses were performed using the SPSS version 25 (SPSS Incorporated, Chicago, Illinois, USA) software. A p value of $<0.05$ was considered statistically significant for all test results in the manuscript.

\section{RESULTS}

All of the patients who were included into the study were females, and mean age of the 41 patients was found as $50.12 \pm$ 8.63 (range $=36-71$ years). While 19 of the patients were premenopausal or perimenopausal, 22 were postmenopausal. The average number of labor of the patients was $1.93 \pm 0.68(0-3)$ and their average breastfeeding durations were $19.56 \pm 14.08$ (0-72) months. First degree relatives of 7 cases, to whom biopsy was performed, had a history of breast cancer. Two of the patients had the history of breast cancer themselves and 1 of them had the history of ovarian cancer.

Distribution of breast lesions in breast quadrants and sonographic breast compositions assessed with ultrasound prior biopsy are shown in Figures $1 \mathrm{a}$ and $1 \mathrm{~b}$. Lesion dimensions were $(4-20) \times(3.5-10) \times(3-14) \mathrm{mm}$, the longest diameter of all lesions 
was $\leq 20 \mathrm{~mm}$. Mean of the longest dimension of all lesions was $9.04 \pm 3.5 \mathrm{~cm}$. The volume of lesions was between 0.018-1.05 $\mathrm{cm}^{3}$ and mean volume of lesions was found as $0.206 \mathrm{~cm}^{3}$. Histopathologic diagnosis of the lesions was as follows: 16 fibroadenoma, 11 intraductal papilloma, 3 invasive carcinoma, 2 in situ carcinoma, 1 fat necrosis, 1 extensive fibrosis, 15 patients had benign diagnosis like fibrocystic changes, fibroadenomatoid changes, and adenosis. In 3 cases of fibroadenoma and papilloma, one of the high-risk lesions, atypical ductal hyperplasia $(\mathrm{ADH})$, was also reported. In addition to fibroadenoma and papilloma, sclerosing adenosis was reported in 3 cases ans fat necrosis in one. Histopathologic results and BI-RADS category of the lesions are given in Table 1. Of the total 50 lesions, while 1 (2.5\%) of the lesions categorized as BI-RADS 4A was malignant, 2 (20\%) of the lesions categorized as BI-RADS 4B were malignant and 2 (20\%) of them were diagnosed as in-situ cancer (Table 1). Of all the lesions, $84 \%$ was benign, $6 \%$ was $A D H, 4 \%$ was in-situ cancer, and 6\% was diagnosed as malign.

Complications of the 41 patients during biopsy were as follows: vasovagal-induced seizure/syncope in 3 (7.3\%) patients and

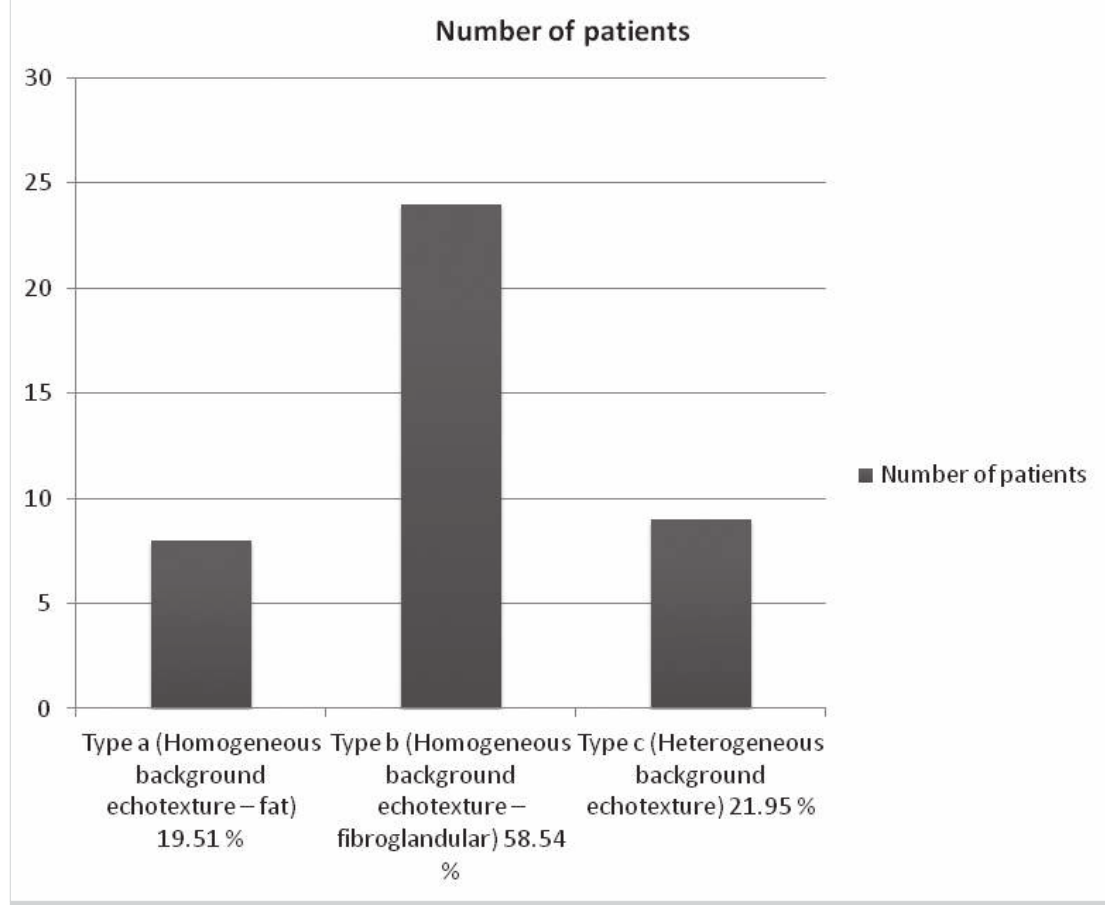

Figure 1. Breast compositions assessed with ultrasound.
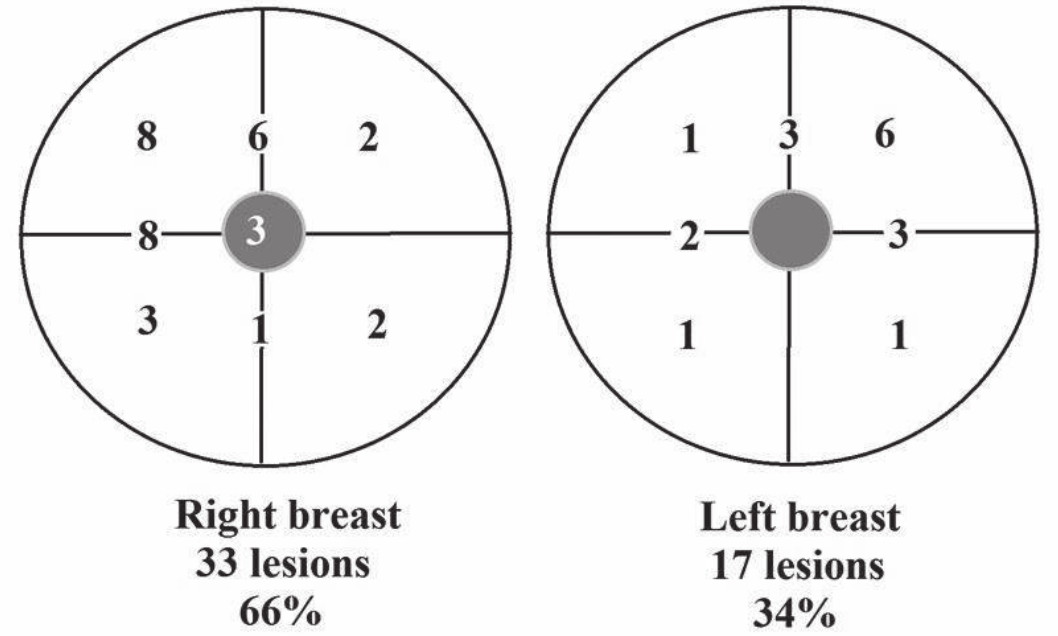

Figure 2. Distribution of lesions with regard to breast quadrants. 
Table 1. Histopathologic results due to BI-RADS category of lesions

\begin{tabular}{|l|c|c|c|c|c|}
\hline \multirow{2}{*}{ BI-RADS category } & \multirow{2}{*}{$\mathbf{n}$} & \multicolumn{3}{|c|}{ Pathological results of US-guided VABB } & \multirow{2}{*}{ Benign } \\
\cline { 2 - 5 } & Invasive carcinoma & In situ carcinoma & Atypic ductal hyperplasia & $36(90 \%)$ \\
\hline 4A & 40 & $1(2.5 \%)$ & $0(0 \%)$ & $3(7.5 \%)$ & $6(60 \%)$ \\
\hline US & 10 & $2(20 \%)$ & $2(20 \%)$ & $0(0 \%)$ & 6 \\
\hline
\end{tabular}

Table 2. The relationship between BI-RADS and hematoma development

\begin{tabular}{|l|c|c|c|}
\hline & Hematoma presence & Hematoma absence & p \\
\hline BI-RADS 4A & $11(27.5 \%)$ & $29(72.5 \%)$ & 0.172 \\
\hline BI-RADS 4B & $5(50.0 \%)$ & $5(50.0 \%)$ & \\
\hline p value obtained with chi-square test. & & & \\
\hline
\end{tabular}

intramammary hematoma in 16 (39\%) patients. In a patient, bleeding as leakage continued for 24 hours from the incision line and limited itself in 24 hours. During US-guided VABB, hematoma was detected in all 3 patients whose lesions were diagnosed as invasive cancer. Of all the 50 lesions, five were diagnosed as invasive or in situ cancer, and curative surgery was performed on these patients. Patients underwent breast-sparing surgery and sentinel lymph node sampling. After US-guided $\mathrm{VABB}$, with the occurrence of hematoma, the lesion site became palpable. Hematoma and tissue changes were used in localizing surgery area and to these lesions, additional wire placement was not executed in our three patients.

The patients who underwent curative surgery were excluded from the follow-up evaluation in terms of the changes at the wound site. Also, two patients (3 lesions) did not attend follow-up ultrasound. A patient attended just $3^{\text {rd }}$-month ultrasound control and another patient attended $6^{\text {th }}$ month follow-up. The follow-up duration for the rest of the patients was one year or above. Follow-up duration of the patients was between 0-51 months and mean was 20.92 months. Of the 41 lesions (after subtracting malign-premalignant ones and the ones who did not attend follow-up), organized hematoma was diagnosed in $3(7.3 \%)$ at the $6^{\text {th }}$ month follow-up. Hematoma disappeared in all of the 13 patients (the patients for whom hematoma developed and followed-up) in the $12^{\text {th }}$ month.

Breast compositions of the patients who developed hematoma were ACR type in 2 patients (25\% of all type a), ACR type b in 10 patients ( $41 \%$ of all type b), and ACR type c in 4 patients ( $44 \%$ of all type c). While the average sample number in the group which developed hematoma during the procedure was 14.63 \pm 5.12 , it was $12.82 \pm 5.96$ in the group without hematoma development. According to t-test results, there was no significant difference between the groups on the sample number of vacuum aspiration [t (48) $=-1.041, \mathrm{p}=0.303]$.

Hematoma was detected in 11 of 40 BI-RADS 4A lesions (0.275) and 5 of $10 \mathrm{BI}$-RADS $4 \mathrm{~B}$ lesions (0.5). T-test was utilized to under- stand whether the mean sample number of vacuum aspiration varied by BI-RADS subgroups (4A and 4B). According to t-test results, there was no difference between the BI-RADS subgroups (4A and $4 B$ ) on the sample number of vacuum aspiration [ $t$ $(48)=-0.927, p=0.359]$. Mean number of vacuum aspirations were recorded as $13.03 \pm 5.59$ for BI-RADS 4 A and $14.9 \pm 6.28$ for BI-RADS 4B. Hematoma was observed in 11 (27.5\%) cases within BI-RADS 4A group where hematoma was not seen in 29 (72.5\%) cases. On the other hand, BI-RADS 4B group involved 5 (50.0\%) cases with hematoma and 5 (50.0\%) cases without hematoma. In order to understand group-wise differences between the BIRADS subgroups and hematoma development, chi-square test was implemented. Test results revealed that there was no significant difference between BI-RADS subgroups and hematoma development $\left[X^{2}(1)=1.861, p=0.172\right.$, Table 2].

A binary logistic regression was performed to ascertain the effects of vacuum aspiration sample numbers and lesions volume on the likelihood of hematoma development. The logistic regression model was not significant for the relationship between vacuum aspiration sample number and hematoma development $X^{2}(1)=1.089, p=0.297$. The model explained only $3 \%$ (Nagelkerke $\mathrm{R}^{2}$ ) of the variance in hematoma development and correctly classified $66.0 \%$ of the cases. Increasing vacuum aspiration was associated with an increased likelihood of exhibiting hematoma development at $b=0.056$; however, this association was not significant ( $p=0.299)$. In a similar vein, lesion size, which was initially considered as a predictor of hematoma development, was not supported according to the logistic regression model $X^{2}(1)=0.086, p=0.769$. The model explained only $0.2 \%$ (Nagelkerke $\mathrm{R}^{2}$ ) of the variance in hematoma development and correctly classified $68.0 \%$ of the cases. Increasing lesion volume was associated with a reduction in the likelihood of exhibiting hematoma development at $b=-0.434$; however, this association was not statistically significant $\mathrm{p}=0.772$ (Table 3 ).

During follow-up, resiude lesion in 1 (2.4\%) patient and scar tissue in 2 (4.9\%) patients scar were detected. The dimension of 
Table 3. Binary logistic regression results for the relationships between lesion/vacuum aspirations and hematoma development

\begin{tabular}{|c|c|c|c|c|c|c|c|c|c|}
\hline \multirow[b]{2}{*}{ Models } & \multirow[b]{2}{*}{ Variables } & \multirow[b]{2}{*}{ B } & \multirow[b]{2}{*}{ s.e. } & \multirow[b]{2}{*}{ Wald } & \multirow[b]{2}{*}{ df } & \multirow[b]{2}{*}{$\mathbf{p}^{*}$} & \multirow[b]{2}{*}{$\operatorname{Exp}(B)$} & \multicolumn{2}{|c|}{$95 \%$ C.I. for $\operatorname{Exp}(B)$} \\
\hline & & & & & & & & Lower & Upper \\
\hline 1 & vacuum aspirations & 0.056 & 0.053 & 1.079 & 1 & 0.299 & 1.057 & 0.952 & 1.174 \\
\hline 2 & lesion & -0.434 & 1.5 & 0.084 & 1 & 0.772 & 0.648 & 0.034 & 12.247 \\
\hline
\end{tabular}

Dependent variable $=$ hematoma development $(0=$ absence and $1=$ presence $)$

$p$ value obtained from the variable in the equation.

the lesion was $10 \times 7 \times 10 \mathrm{~mm}$ for the residue lesion, and it was sampled 8 times. Histopathologic diagnosis of 2 cases, in whom scar developed, was fibrocystic changes and sclerosing adenosis, and both lesions were sampled 14 times.

\section{DISCUSSION}

This study showed that hematoma, which is the most common early complication in US-guided VABB, disappeared in all of the patients in the $12^{\text {th }}$ month. It was also shown that US-guided VABB should be the primarily preferred biopsy method in $\mathrm{Bl}$ RADS $4 A$ and $4 B$ lesions which are smaller than $2 \mathrm{~cm}$ due to its low complication rates, low scar formation in follow-up and low residue rates with its curative property. Today, percutaneous imaging-guided breast biopsies have replaced excisional biopsies and become the gold standard biopsy method (2). When core biopsy and vacuum biopsy are compared, lower underestimation, rebiopsy, and false negative rates are among the superiorities of VABB $(7,11)$. VABB is a biopsy method performed easily within the US, and complications like hematoma can be followed with real-time US (7).

According to the American College of Radiology, risk estimates for malignancy in BI-RADS 4A category (low suspicious) is $\geq 2$ to $<10$, in BI-RADS 4B category (moderate suspicious), is $\geq 10$ to $<50$ and in BI-RADS 4C category (high suspicious) is $\geq 50$ to $<95$ (12). Among all lesions on which biopsy was performed, $6 \%$ (2.5\% of BI-RADS 4A, $20 \%$ of BI-RADS 4B) was diagnosed as malign. VABB provides full excision in BI-RADS $4 A$ and $4 B$ lesions which have a relatively low probability of malignancy if lesions are small in size and benign, thus it inhibits complications and expenses of additional surgery. In the case of malign diagnosis, performing curative cavity surgery is compulsory since surgical margin positivity can not be assessed.

VABB could also be used in BI-RADS 3 lesions like fibroadenomas as a therapeutic procedure, in addition to the use for diagnostic purpose in malignant lesions $(9,13)$. In our study, $84 \%(n=42)$ of all lesions was diagnosed as benign, and residue was detected only in one of them during follow-up. In this study population, the therapeutic effect of VABB benefited in nearly all of the cases which were histopathologically benign. In the literature, residue/ recurrence was not detected in $84.9 \%$ of the lesions in more than one year follow up US-guided VABB (7). The largest diameter of the lesions was $2 \mathrm{~cm}$ and the rate of residual lesion was found as $2.4 \%$ in our series. ADH accompanied three benign lesions in our study. In the literature, it is shown that underestimation rates of $\mathrm{ADH}$ are very low in US-guided VABB (14). In our study, open surgery was not performed in the cases diagnosed as ADH with VABB due to very low rates of underestimation, but they were followed radiologically. In these three patients, mass development or recurrence was not detected at the biopsy site.

In our study, intramammary hematoma developed in 16 (39\%) patients during biopsy. A study held with an 11G needle US-guided biopsy performed in 406 patients has shown that the most frequent complication was bleeding and hematoma, and minor complication rates have been reported as 9\%. However, when the complications occurred was not specified and late-period complications were not mentioned in the aforementioned study (15). In another study, in which late-period complication follow-up was not fulfilled, the rate of early complications was reported as $1 \%$ and hematoma was the most frequent one (7). Higher hematoma rates in our study compared to those of the literature may originate from the goal of excising all lesions or early periods of the follow-up ultrasound. In a study, the rate of hematoma detected by USG has been given as $94 \%$ in the $1^{\text {st }}$ week and $55 \%$ in the $3^{\text {rd }}$ week following stereotactic VABB (16). Hematomas were resorbed during follow-up and the rates of hematoma decreased in follow-up in our study, too. In addition to that, the rate of hematoma was $7.3 \%$ in the $6^{\text {th }}$ month andall hematomas disappeared in the $1^{\text {st }}$ year follow-up in our study. Similar to our study, 9.6\% of the hematomaa was identified in a study in which US-guided VABB was performed for benign breast lesions, and then $97.0 \%$ of the hematomas was entirely absorbed in the $6^{\text {th }}$ month (17).

In our study, higher breast density resulted in higher hematoma rates, and breast density might be a risk factor in hematoma development. Besides, when patients who had a hematoma were considered, no difference was shown between the breast composition types on the sample number. So, breast composition may have an effect in the development of hematoma independent of the sample number. No significant difference between lesion BI-RADS subgroups (4A and 4B) and hematoma development was shown in our study. To our knowledge, there was no study evaluating the effect of breast composition or lesion BI-RADS subgroup on hematoma development with this procedure. To understand the relationship, further studies are needed. 
In our study, hematoma occurred in all three patients, who were diagnosed as invasive cancer, during VABB, which may be related to neovascularization of the tumor. In a study, risk factors of hematoma occurrence after US-guided has been evaluated and the size and number of the nodules, menstrual status, and breast shape have been found as independent risk factors associated with hematoma development (17). As opposed to that study, in our study, we found that the occurrence of hematoma after VABB was not associated with the the size of the lesion or the sampling number of vacuum aspiration. Hematoma development might be related to the abundance of surrounding blood vessels adjunct to the lesions. Vascular structures around the lesion and the tractus visible on the US may be evaluated to understand the relationship between hematoma occurrence and location of the vascular structures. The sampling number of vacuum aspiration may correlate with the experience of the operator. In our study, we didn't find any relation with the number of sampling and hematoma, and to our knowledge, there is no study mentioning or evaluating this parameter.

In our patient group, we took advantage of hematoma occurrence in malignant lesions in determining the site of the lesion without the necessity of additional wire guiding before cavity surgery. Studies are needed to show its applicability in routine practice.

Vasovagal-induced seizure/syncope occurred in three patients (7.3\%) during biopsy. In a study, in which US-guided VABB was performed on 67 patients, this rate was found as 1\% (18). Our vasovagal seizure/syncope rate was higher than this study. As the mechanism of this complication is about fear in patients, socio-cultural differences might explain the high rate in our study. In our study, scar tissue developed in two lesions (4.9\%), sampled for 14 times. In another study similar to ours, in which stereotactic VABB using $11 \mathrm{G}$ needle was assessed, scar development was found as $4.3 \%$, and these cases were ensampled averagely for 12 times (19).

In our study, we showed that US-Guided VABB inhibits additional surgery in BI-RADS $4 \mathrm{~A}$ and $4 \mathrm{~B}$ breast lesions which are smaller than $2 \mathrm{~cm}$ and pathologically proven as benign lesions with low complication rates, and it is both a biopsy and treatment method in these lesions. Due to these superior properties, US-guided VABB should be the initial biopsy method in BI-RADS $4 A$ and $4 B$ lesions whose malignancy rates are as low (2.5\%-6\% in our series), by considering its easy applicability, providing a sufficient number of sample and therapeutic effects in breast lesions.

The main limitation of our study is the retrospective design and the limited number of cases. The other limitation of this study is all breast ultrasounds and US-guided vacuum-aspiration biopsies were performed by only one radiologist. Therefore, we cannot evaluate the interoperator variabilities of complications and rates. Further studies should consider at least two indepen- dent observers (or radiologist) in order to assess the agreement between the raters which may help us evaluate the reliability of the measurements in a more objective manner. Moreover, a follow-up evaluation of 6 patients were less than 6 months. The number of BI-RADS $4 \mathrm{~A}$ and $4 \mathrm{~B}$ lesions was not equal, and malignant results were very low in number.

\section{CONCLUSION}

US-guided VABB, which can be tolerated easily and have low rates of complication and scar development, is also a therapeutic excision method without residual lesion, which should be primarily preferred in BI-RADS $4 \mathrm{~A}$ and $4 \mathrm{~B}$ lesions smaller than 2 $\mathrm{cm}$ with low malignancy rates. Hematoma, which is the most frequent complication in US-guided VABB, is also useful in determining the site of lesion in complementary surgery regarding the cases diagnosed as malignant tumor. Hematomas may spontaneously be resorbed entirely in the $12^{\text {th }}$ month.

Ethics Committee Approval: This study had been approved by our medical school's Institutional Reviews Board (number 04/III date 05.04.2018).

Informed Consent: Informed consent was taken from all patients prior to biopsy.

Peer-review: Externally peer-reviewed.

Author Contributions: Concept - F.D.E.; Design - F.D.E., C.E., O.N.; Supervision - F.D.E., A.K.B.; Resource - F.D.E., Y.D., A.K.B., Ö.D.; Materials - Y.D., F.D.E.; Data Collection and/or Processing - C.E., Ö.D., Y.D., O.N.; Analysis and Interpretation - A.K.B., C.E., F.D.E.; Literature Review - F.D.E., C.E.; Writing Manuscript - F.D.E., O.N.; Critical Reviews - F.D.E., Y.D., A.K.B., C.E., Ö.D., O.N

Conflict of Interest: All authors declare no conflict of interest and financial relationships.

Financial Disclosure: The authors declared that this study has received no financial support.

\section{REFERENCES}

1. Liberman L, Feng TL, Dershaw DD, Morris EA, Abramson AF. USguided core breast biopsy: use and cost-effectiveness. Radiology 1998;208:717-23. [CrossRef]

2. O'Flynn EAM, Wilson ARM, Michell MJ. Image-guided breast biopsy: state-of-the-art. Clin Radiol 2010;65:259-70. [CrossRef]

3. Schueller G, Schueller-Weidekamm C, Helbich TH. Accuracy of ultrasound-guided, large-core needle breast biopsy. Eur Radiol 2008;18:176173. [CrossRef]

4. Jung I, Kim MJ, Moon HJ, Yoon JH, Kim EK. Ultrasonography-guided 14-gauge core biopsy of the breast: results of 7 years of experience. Ultrason (Seoul, Korea) 2018;37:55-62. [CrossRef]

5. Huang XC, Hu XH, Wang XR, Zhou CX, Wang FF, Yang S, et al. A comparison of diagnostic performance of vacuum-assisted biopsy and core needle biopsy for breast microcalcification: a systematic review and meta-analysis. Irish J Med Sci 2018;187:999-1008. [CrossRef]

6. Spick C, Schernthaner M, Pinker K, Kapetas P, Bernathova M, Polanec SH, et al. MR-guided vacuum-assisted breast biopsy of MRI-only lesions: a single center experience. Eur Radiol 2016;26:3908-16. [CrossRef] 
7. LeeSH, Kim EK, Kim MJ, Moon HJ, Yoon JH. Vacuum-assisted breast biopsy under sonographic guidance: analysis of 10 years of experience. Ultrasonography 2014;33:259-66. [CrossRef]

8. Yao F, Li J, Wan Y, Zhong Y, Wei W, Tu Y, et al. Sonographically guided vacuum-assisted breast biopsy for complete excision of presumed benign breast lesions. J Ultrasound Med 2012;31:1951-7. [CrossRef]

9. Buğdaycı O, Kaya H. Ultrasound guided therapeutic excisional vacuum assisted biopsy in breast fibroadenomas. J Breast Heal 2017:74-6. [CrossRef]

10. Park HL, Kim LS. The current role of vacuum assisted breast biopsy system in breast disease. J Breast Cancer 2011;14:1. [CrossRef]

11. Cho N, Moon WK, Cha JH, Kim SM, Kim SJ, Lee SH, et al. Sonographically guided core biopsy of the breast: comparison of 14-gauge automated gun and 11-gauge directional vacuum-assisted biopsy methods. Korean J Radiol 2005;6:102-9. [CrossRef]

12. American College of Radiology. Breast Imaging Reporting \&amp; Data System, BI-RADS: Mammography. $5^{\text {th }}$ ed. Reston, VA: 2013. [CrossRef]

13. Hahn M, Krainick-Strobel U, Toellner T, Gissler J, Kluge S, Krapfl E, et al. Interdisciplinary consensus recommendations for the use of vacuumassisted breast biopsy under sonographic guidance: first update 2012 Ultraschall Der Medizin - Eur J Ultrasound 2012;33:366-71. [CrossRef]
14. Grady I, Gorsuch H, Wilburn-Bailey S. Ultrasound-guided, vacuumassisted, percutaneous excision of breast lesions: an accurate technique in the diagnosis of atypical ductal hyperplasia. J Am Coll Surg 2005;201:14-7. [CrossRef]

15. Cassano E, Urban LABD, Pizzamiglio M, Abbate F, MaisonneuveP, Renne $G$, et al. Ultrasound-quided vacuum-assisted core breast biopsy: experience with 406 cases. Breast Cancer Res Treat 2007;102:103-10. [CrossRef]

16. Hertl K, Marolt-Music M, Kocijancic I, Prevodnik-Kloboves V, Zgajnar J. Haematomas after percutaneus vacuum-assisted breast biopsy. Ultraschall Der Medizin - Eur J Ultrasound 2008;30:33-6. [CrossRef]

17. Huo HP, Wan WB, Wang ZL, Li HF, Li JL. Percutaneous removal of benign breast lesions with an ultrasound-guided vacuum-assisted system: influence factors in the hematoma formation. Chinese Med Sci J 2016;31:31-6. [CrossRef]

18. Simon JR, Kalbhen CL, Cooper RA, Flisak ME. Accuracy and complication rates of US-guided vacuum-assisted core breast biopsy: initial results. Radiology 2000;215:694-7. [CrossRef]

19. Yazici B, Sever AR, Mills P, Fish D, Jones SE, Jones PA. Scar formation after stereotactic vacuum-assisted core biopsy of benign breast lesions. Clin Radiol 2006;61:619-24. [CrossRef]

\title{
ORIJINAL ÇALIŞMA-ÖZET
}

Turk J Surg 2020; 36 (1): 65-71

\section{BI-RADS 4A ve 4B lezyonlarda hem bir tanı hem de tedavi yöntemi: Ultrason eşliğinde vakum aspirasyon biyopsisi}

\author{
Funda Dinç Elibol ${ }^{1}$, Yelda Dere ${ }^{2}$, Ahmet Korkut Belli ${ }^{3}$, Cenk Elibol ${ }^{1}$, Özcan Dere ${ }^{3}$, Okay Nazlı ${ }^{3}$ \\ ${ }^{1}$ Muğla Sıtkı Koçman Üniversitesi Tıp Fakültesi, Radyoloji Anabilim Dalı, Muğla, Türkiye \\ ${ }^{2}$ Muğla Sıtkı Koçman Üniversitesi Tıp Fakültesi, Patoloji Anabilim Dalı, Muğla, Türkiye \\ ${ }^{3}$ Muğla Sıtkı Koçman Üniversitesi Tıp Fakültesi, Genel Cerrahi Anabilim Dalı, Muğla, Türkiye
}

\section{ÖZET}

Giriş ve Amaç: Bu çalışmada, ultrason eşliğinde vakum aspirasyon biyopsisi yapılan BI-RADS 4A ve 4B lezyonlarda sonuçların, komplikasyonların ve takip sonuçlarının değerlendirilmesi amaçlanmıştır.

Gereç ve Yöntem: Çalışmada Ağustos 2014-Ocak 2018 tarihleri arasında hastanemizde tek bir radyolog tarafından 10G vakum aspirasyon biyopsi iğnesi ile biyopsisi yapılan 50 BI-RADS 4A ve 4B lezyona ait veriler retrospektif olarak değerlendirildi.

Bulgular: Tüm hastalar kadındı ve yaş ortalaması 50,12 \pm 8,63 yıl idi. Tüm lezyonların \%84'ü benign, \%6'sı ADH, \%4'ü in situ kanser ve \%6'sı malign tanı almıştır. Biyopsi sonrası takip süresi 0-51 ay olup ortalaması 20,92 ay olarak bulunmuştur. İşlem sırasında komplikasyonlar; 3 (\%7,3) hastada vazovagal senkop, $16(\% 39)$ hastada meme içi hematom şeklindeydi. Hematom altıncı ay kontrolünde $3(\% 7,3)$ hastada saptanırken, 12 . ay kontrolünde tüm hematomlar kaybolmuştur. Lezyon BI-RADS alt grupları, boyutu veya örnek sayısı ile hematom gelişimi açısından anlamlı bulunmamıştır. Takipte $1(\% 2,4)$ hastada rezidü lezyon, $2(\% 4,9)$ hastada ise skar dokusu saptanmıştır.

Sonuç: Ultrason eşliğinde vakum aspirasyon biyopsisi düşük komplikasyon ve skar oranları olan ve rezidü bırakmadan tedavi edici eksizyon da sağlayan, 2 cm'den küçük, malignite olasılıkları nispeten düşük BI-RADS 4A ve 4B lezyonlarda ilk terich edilmesi uygun olan biyopsi yöntemidir. Hematom en sık komplikasyonu olup, 12. ayda tüm olgularda tümüyle kaybolmuştur.

Anahtar Kelimeler: Ultrason eşliğinde vakum aspirasyon biyopsisi, BI-RADS, komplikasyon, tedavi

Doi: $10.5578 /$ turkjsurg. 4472 